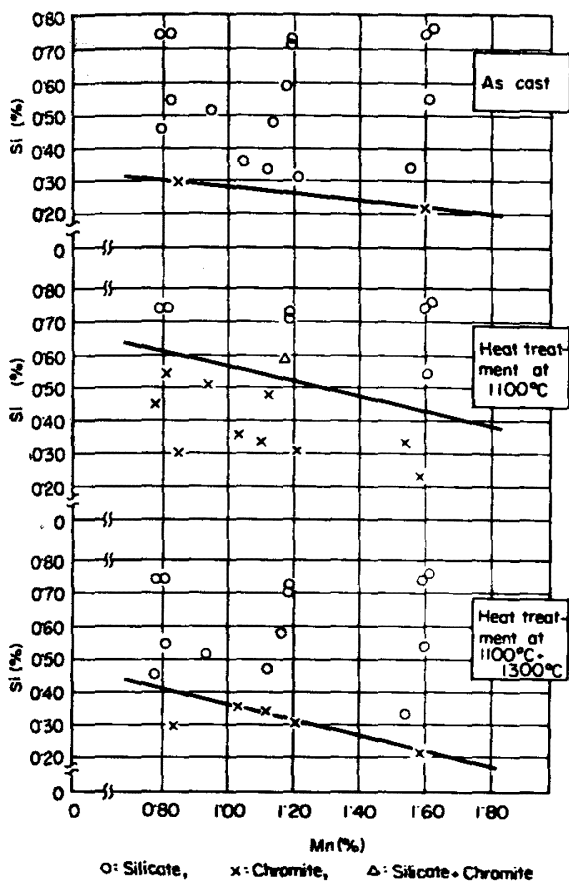

Fig. 3. Influence of $\mathrm{Si}$ and $\mathrm{Mn}$ content on the type of oxide inclusion in 18-8 stainless steel.

えられず，一般には18-8 ステンレス筒中の介在物は鋳 込みのまをで Mn-silicate, $1100^{\circ} \mathrm{C}$ 加整で Mn-chromitたは Mn-silicate, $1300^{\circ} \mathrm{C}$ 加熟では Mn-silicate であるといえよう。

\section{4. 结}

18-8 ステンレス釗を $\mathrm{Si}, \mathrm{Mn}$ で瞣酸し，主として 固封に晶出する介在物について，加熟による組成変化を 請へた結果，地金中の $\mathrm{Si} ， \mathrm{Mn}$ 量が介在物の組成変化に 大きな影䇺をおよほすことがわかり，地金中の $\mathrm{Si}, \mathrm{Mn}$ 量と介在物組成の関係を明らかにすることができた。

\section{キルド鋼の内部欠陷およひ表面欠} 陷改芲に対する 2,3 の考察

富士慗鉄，室獭製鉄所

都筑誠毅・工博 恵藤文二・ ○皇山卓三

Some Consideration on Improvement of Internal and Surface Defects of Killed Steel Seiki Tsuzukı, Dr. Bunji Eтo and Takuzo HATAKEYAMA

\section{1. 絠}

キルド鐳の造塊についてはわれわれは成塊の表面状況 の改著および内質の向上を目橙として今まで種々の調査 梌討を加えてきており最近ほほ满足すべき結果が得られ たので垠告する. 注入温度と銅塊の割れおよび銅材の清
浄度については併来から影著な相関関倸のあることが報 告されており注入温度の現場的な管理は造塊上重要な要 因である。また割れについて注入温度とともに注入速 度も問而になるが実際の作業上管理の範囲が限られる。 したがつてまず上記の問題の定量的な検討を行なつた。 つぎに銅塊の表面品質を改善するため酸化防止唁を使用 してその効果の検討を行なつた.

\section{2. 箱查方法}

キルド銅の造塊技術を向上させるために次の項目につ いて調查検討を行なつた。なお調査はすべて平奶工場内 の $50 \mathrm{t}$ 小型枟奸出铜の溶銅を下注造塊したものを対象 にして行なつた。

\section{$2 \cdot 1$ 注入温度と割れについて}

注入温度を变化させて分塊鋾片に発生する割れを分塊 割れ評点として測定した。ただしこの評点方法は分塊口 一ルの側面から銅片の四面に発生する割れを観察して大 きさにより大 2 点, 小 1 点, とし筒塊 1 本当たりに発生 した分塊割れの総数を分塊割れ評点とした。

$2 \cdot 2$ 注入温度と清浄度地キズ成繶について

注入温度を変化させて銅材の清浄度地キズ成績を調查 した、調査方法は JIS 法によつた。

2.3 酸化防止靔の効果について

造塊中に粉状の酸化防止唁を使用し冷塊および銅片を 钼察してその奻果の検討を行なつた.

\section{3. 調枯結果および考察}

\section{1 注入温度と割れについて}

銅塊の割れもしくはそれに起因して発生する分塊鋼片 の割れについては従来から種々調查検討されてきた結果 これらの割れにおよほす要因として注入方法, 铜種, 注 入温度, 注入速度, 銿型形状などが考えられている. 注 入温度と割れ（分塊堸片の割れ評点で表示）との関係に ついては, Fig.1に示したごとくで高温注入が制れ発生 の原因の1つになるものと考えられる.ただし调查は $\mathrm{S} 45 \mathrm{C}$ クラスの下注キルド銅で行なつた。この帮れの 発生率が急激に上舁する出鍶温度の上限は工場の条件に よつて異なるがわれわれの工場では $1640^{\circ} \mathrm{C}$ 程度であろ うと考えられる.

注入温度は一方銅材の清浄度や地キズ成繶など，二の 内頁にも大きい影鹤をおよぼすものと考えられるので， 割れの減少対策のみから出銅温度を検討することはでき ない.

3.2 注入温度と清浄度地キズ成稍について

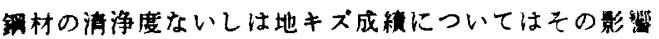
をおよぼす要因が沢山あつてこれといつた決め手はまだ 見い出されてないようであり，精鍊，脱酸，造塊と製鋼 過程全体の中で非金属介在物の溶銅中での举的を考えて みる必要があろう. 今回われわれは 3.1の“注入温度 と割れについて”と閶連して現場的に“注入温度と清 浄度ならひに地キズ成樍について”調查検討を行なつ た。

Fig. 2 S45C クラスのキルド銅を对象にした注入 温度と消浄度についての調査結果を示す. Fig. 2 から明

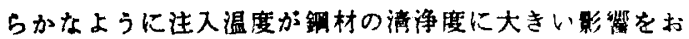
よほするのと考えられ, 低温注入が清浄度を窑する要因 になつているものと思われる.つまり Fig. 2 で低温注 
Table 1. Relation between teeming temperature and macro-streak flow.

\begin{tabular}{l|c|c|c|c}
\hline \hline Teeming temperature & Number of charges & Number of samples & Frequency of streaks & Length of max. streaks \\
\hline High teeming temp. & 60 & 120 & $8 \cdot 3 \%$ & $5 \sim 12(\mathrm{~mm})$ \\
Low teeming temp. & 12 & 24 & $15 \cdot 4 \%$ & $10 \sim 40(\mathrm{~mm})$ \\
\hline
\end{tabular}

Table 2. Composition of test powder.

\begin{tabular}{c|c|c|c|c|c|c|c}
\hline \hline Element & $\mathrm{SiO}_{2}$ & $\mathrm{Al}_{2} \mathrm{O}_{3}$ & $\mathrm{FeO}$ & $\mathrm{CaO}$ & $\mathrm{MgO}$ & Ignition loss & Total carbon \\
\hline Percent & 52.00 & $17 \cdot 80$ & 1.71 & 4.28 & 2.22 & $10 \cdot 35$ & $7 \cdot 10$ \\
\hline
\end{tabular}

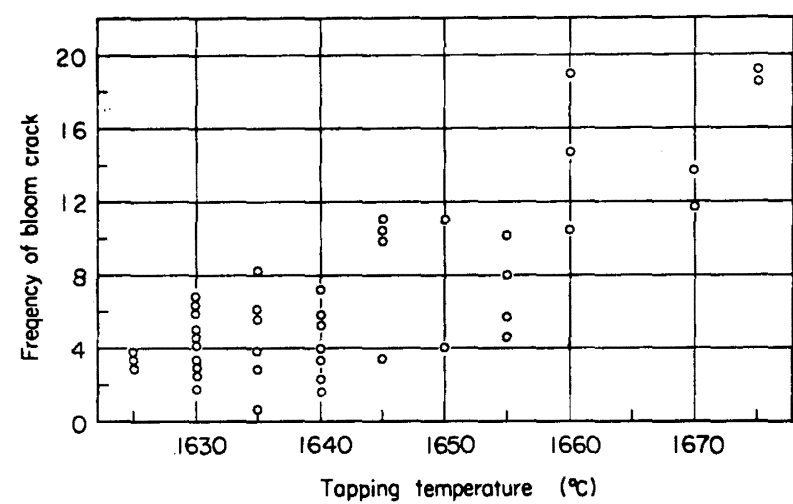

Fig. 1. Relation between tapping temperature and bloom crack.

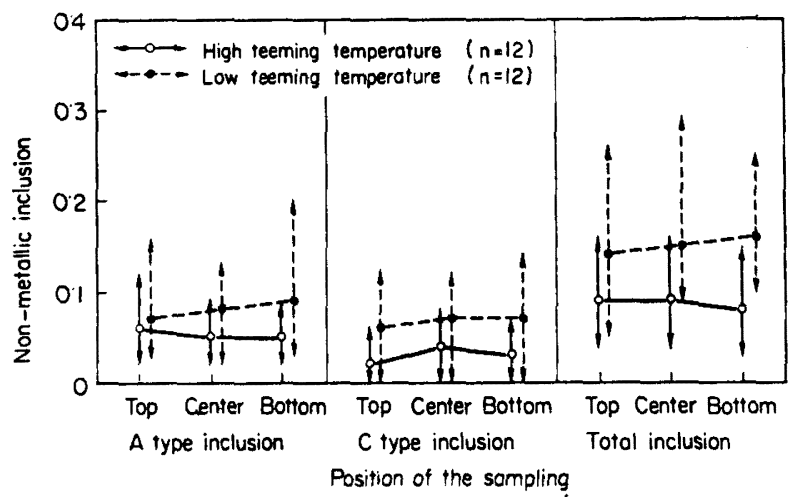

Fig. 2. Relation between tapping temperature and nonmetallic inclusion.

入ヒートにおいてA型介在物 C 型介在物，したがつて介 在物合㖕がいずれも高温注入ヒートよりも多くなつてお り，またバラッキむ大きくなつている，なお銅塊部位別 にどの部位の海净度が特に悪いという顕著な傾向は見ら れなかつた.ただしここでいう低温注入ヒートは現在の 出銅温度目根以下で出鎆したヒ一ト，高温注入ヒ一トは 目標温度およびそれ以上の温度で出鍴したヒートであ る. 次に Table 1 に S45C クラスのキルド鐥を対象 にした注入温度と地キズ成橉についての調査結果を示 す.表の低温注入ヒート, 总温注入ヒートは, 注入温度
と清浄度の関係についての調查の場合と同槏の分 け方をした. Table 1 に明らかなごとく注入温度

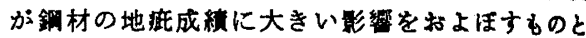
考えられ，高温注入が地キズ成核を向上させる一 つの要因になるものと考えられる.

以上注入温度と清浄度地キズ成棈についての副 查から清浄度や地キズ成糞など嵞材の内貿を向上 させるためには高温注入が非常にいい結果をるた らすことが確められた。

3.3 酸化防止削の効果について

3.1 および 3.2 の調查結果から注入温度は颌片 の揢れと鋼材の内資に逆の效果をおよほすととが 確認された。つまり高温注入するととによって洋 浄度，地キズなど銈材の内筫が大いに改善される 反面，鋼塊に割れの発生する確事が增大し，した がつてそれに起因する分塊割れの発生する割合る 増加する.われわれはキルド銅造塊の方向として 内筫に重点をおき，割れなど鋼塊の表面品页の政

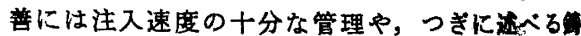
肌改善用の酸化防止削の採用などで解決するとい うことで出銅温度基準を決めた。なお，この出出 温度基集を定める時には，当造塊工場における出 銅時から注入時に至るまでの溶釾の温度降下星を も测定して考にした。次に铸肌改普用粉状酸化 防止绪の効果について調査した結果を述べる.

$3.3 \cdot 1$ 酸化防止埥の組成

使用した酸化防止唁の組成を Table 2 に示オ. 3.3.2 酸化防止㔀の使用方法および使用状況 粉状酸化防止绪を入れた紙袋を鋳型上部加ら啤

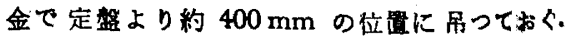

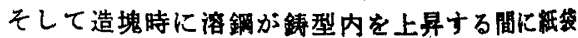
が破れ酸化防止詴は溶銅表面を往うことになる。

それによつて造塊中の溶銅は外気と遮断され、を の空酸化が防止される一方，溶銅表面は保温されて造 塊中に酸化被膜が形成されるのが防止される。的肤 は S45C クラスの下注キルド鋿を対象にして厉ない，

Table 3. Frequency of ingot crack.

\begin{tabular}{c|c|c|c|c}
\hline Period & $\begin{array}{c}\text { Number } \\
\text { of heats }\end{array}$ & $\begin{array}{c}\text { Number of } \\
\text { ingots }\end{array}$ & $\begin{array}{c}\text { Number } \\
\text { of cracks }\end{array}$ & $\begin{array}{c}\text { Crack } \\
\text { percent }\end{array}$ \\
\hline I & 40 & 480 & 48 & $10.0 \%$ \\
I & 40 & 480 & 3 & $0.6 \%$ \\
\hline
\end{tabular}


Table 4. Frequency of bloom crack.

\begin{tabular}{|c|c|c|c|c|c|c|c|c|c|c|c|c|}
\hline \multirow[b]{2}{*}{ Period } & \multirow{2}{*}{$\begin{array}{c}\text { Number } \\
\text { of } \\
\text { blooms } \\
(\%)\end{array}$} & \multirow{2}{*}{$\begin{array}{c}\text { A class } \\
\text { (very good) } \\
(\%)\end{array}$} & \multicolumn{5}{|c|}{ B class (good) } & \multicolumn{5}{|c|}{$C$ class (no good) } \\
\hline & & & $\begin{array}{c}\text { Crack } \\
(\%)\end{array}$ & $\begin{array}{l}\text { Scab } \\
(\%)\end{array}$ & $\left|\begin{array}{c}\text { Brick } \\
\text { inclusion } \\
(\%)\end{array}\right|$ & $\begin{array}{c}\text { Others } \\
(\%)\end{array}$ & $\begin{array}{c}\text { Total } \\
(\%)\end{array}$ & $\begin{array}{c}\text { Crack } \\
(\%)\end{array}$ & $\begin{array}{l}\text { Scab } \\
(\%)\end{array}$ & \begin{tabular}{|c|} 
Brick \\
inclusion \\
$(\%)$
\end{tabular} & $\begin{array}{c}\text { Others } \\
(\%)\end{array}$ & $\begin{array}{c}\text { Total } \\
(\%)\end{array}$ \\
\hline I & $\begin{array}{c}716 \\
(100)\end{array}$ & $\begin{array}{c}296 \\
(41 \cdot 3)\end{array}$ & $\begin{array}{c}285 \\
(39 \cdot 8)\end{array}$ & $\begin{array}{c}49 \\
(6 \cdot 9)\end{array}$ & $\begin{array}{c}57 \\
(8 \cdot 0)\end{array}$ & $\begin{array}{c}17 \\
(2 \cdot 3)\end{array}$ & $\begin{array}{c}408 \\
(57 \cdot 0)\end{array}$ & $\begin{array}{c}4 \\
(0 \cdot 6)\end{array}$ & $\begin{array}{c}1 \\
(0 \cdot 1)\end{array}$ & $\begin{array}{l}0 \\
(0)\end{array}$ & $\stackrel{7}{(1 \cdot 0)}$ & $\begin{array}{c}12 \\
(1 \cdot 7)\end{array}$ \\
\hline I & $\begin{array}{c}701 \\
(100)\end{array}$ & $\begin{array}{c}504 \\
(71 \cdot 9)\end{array}$ & $\begin{array}{c}143 \\
(20 \cdot 2)\end{array}$ & $\begin{array}{c}27 \\
(3 \cdot 9)\end{array}$ & $\begin{array}{c}18 \\
(2 \cdot 6)\end{array}$ & $\begin{array}{c}5 \\
(7 \cdot 1)\end{array}$ & $\begin{array}{c}193 \\
(27 \cdot 5)\end{array}$ & $\begin{array}{c}2 \\
(0 \cdot 3)\end{array}$ & $\begin{array}{c}2 \\
(0 \cdot 3)\end{array}$ & $\begin{array}{l}0 \\
(0)\end{array}$ & $\begin{array}{c}0 \\
(0)\end{array}$ & $\begin{array}{c}4 \\
(0 \cdot 6)\end{array}$ \\
\hline
\end{tabular}

化防止绪の使用量注鍋塊 $\mathrm{t}$ 当り $1.5 \mathrm{~kg}$ とした。 3.3.3 化防止敖の使用効果

造塊中に酸化防止刹を便用した結果つきのような効果 が認められた.

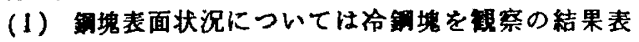
首スカムが娍少し，レンガのかみこみもなくなつて鋳肌 は非常に美麗になつた。 また銅材のスカーフィング後に おいても以前みられたスキンホールは全然なくなりレン ガキズるなくなつた。

（2）塊の割れについては Table 3 に示したごとく 酸化防敖の使用によつて割れ発生来は诚少している。 てれ浩造塊中に酸化被滇の形成されるのが防止され，塎

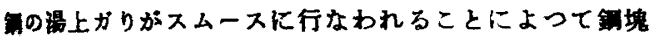
の表面に睯理な力がかからなくなるためであろうと思わ れる.なお Table 3 における期間 1，1はそれそれ酸 化防止削を使用し始める前媵の時期を示す.

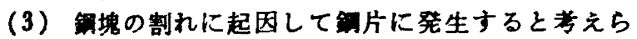
れる分塊割れについての䚴査結果を Table 4 に示す. てれには酸化防止靔を使用しはじめる前後の時期におけ る版に発生するワレ，ーゲ，レンガキズなどの発生事 で京した。期間 I，Iはそれそれ酸化防止敖を使用し 始める前後の時期を示す. 銈片のキズは大半が筑塊の 都れに起因して発生すると考えられるワレキズであり， Table 4 から破化防止靔の使用奻果汢明らかに嫼められ ろ.

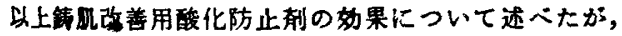
てれを使用するととによつて銅塊鋳肌は非常に美学にな

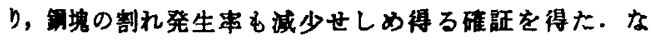
おさらに造塊中の溶銅を外気と遮盽して溶釷の圶気酸化 を防止できることから銅材の清浄度など非金原介在物量 の诚少る期待されたが，ての点に闺しては㬉著な効果は 證められながつた。

\section{4. 桔}

以上当工場におけるキルド釷の造塊について城の表 面品質および内質の向上を目楑に注入温度と割れおよび 㳻净度の成保, 酸化防止靔の新果などについて調查険討 を加えてきた. その結果をむとにして，高温注入のもと で物状硫化防止郕を採用した結果，表面品所ならびに内 置とすにより良好なキルド鍂塊を造塊できるようになつ た.
（111）超音波による銅板ラミネーション の追跡

富士整失，中央研究所

○磯野英二・上野 立・满尾利晴

Tracing of Defects in Steel Plates by Ultrasonic Method

Eiji Isono, Tatsuru Ueno and Toshiharu MrTsuo

\section{1. 绪}

\section{H}

ここ数年来の銅材製品に対して要求される品質の高級 化と，これに対する銅材メ一カーの対策としての品質管 理は，非破鈫検査の採用なしには達成できない段階にあ るといえる。

品質管理上，不良品はできる限り初期の段階で生産の 流れから除去することが原則であるが，技術的に困難な 場合があり，これもそれぞれの現場の特殊事情があるな どして一概には論じられない。

しかしながら鋼板において現在，ラミネーションとし て取上げられている久宿が，スラブ，さらにさかのほつ てインゴットの一連の圧狿行程のなかで，とのような過 程をたどつて亲化しているかの情報をつかんでおくこと は慗銅，造塊上にむ有益なデータを与えると考えられる ので，内部欠樎検出法として現在最も有利な超音波探仵 法により追跡してみることとした。

\section{2. 成方法および式料}

インゴットから慗品に至る一連の哮音波探伤の報告は 1 例1) みられるのみであるが, これも久陷の状況, 超音 波手法の細部については不明である.一方銅板のラミネ ーションと呼ばれているものの定義も明確でないが，こ こでは現在鏋板のユーザーが問原としているもの，广な わち主として切断端面の染色浸透探做，あるいは磁粉探 的によりインデイケーションとして認められ，タレーム の対象となる程度のもの

久宿追跡の方法としては, 人工欠陥あるいは自然欠樎 のある特定の攵陷に着目して，1奶1の対応を見る方法 があり，これらについてはナでに検討してあるので，今 回はFig.1 に示したように，区画されたマス中の久陥 が,インゴットースラブーブレートの過程て，それぞれ どうなるか大体の対応を調べる方法をとることとし た.これによりインゴット，スラブそれぞれの段階での 超音波久陌分布四を求めることができ，造塊，㠜固の状 況む推测できると孝えた。

また本実検は相当大規模になるので，試験をグルーブ 
INGOT

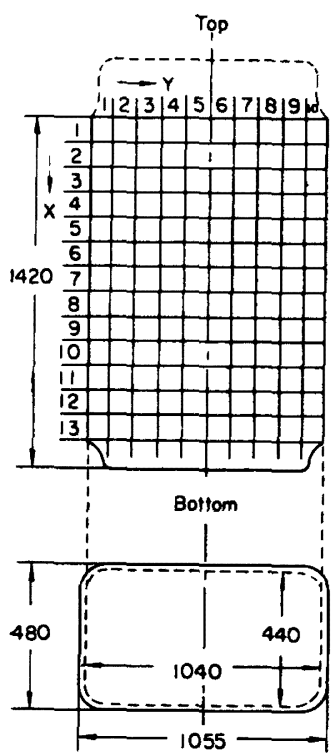

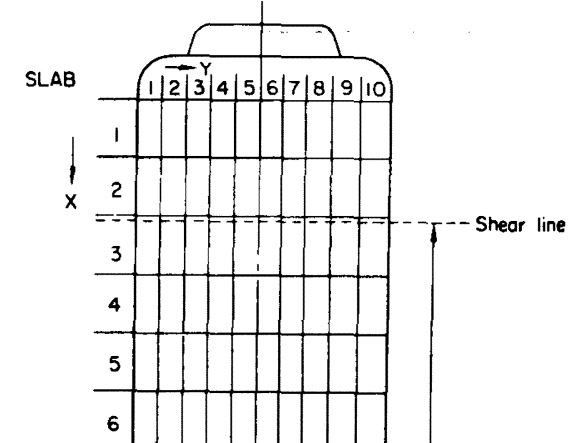

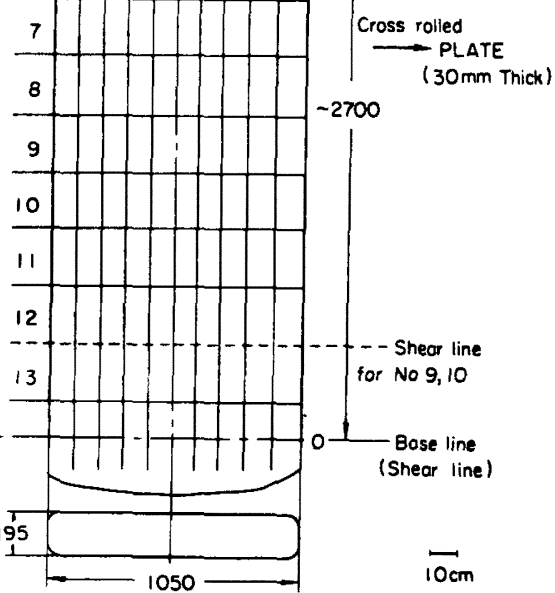

Fig. 1. The size and testing division of ingot and slab.

にわけ,グルーブの結果が次のグルーブの試鍳に反映で きるようにして行なつた．その概要を Table 1 に示す. すなわちラミネーションが発生するような条件と，そう でない条件で溶型造塊された $60 \mathrm{~kg}$ 級高張力铜の $6 \mathrm{t}$, インゴット12 チャージを使用し，インゴット，スラフ では探僬面全面をグラインダ一手入れした後，全面超音 波探伤を行ない，深做法，樲錄法などについて検討し た. またえれそれの代衰的欠陌については，切断端面を 磁粉探侮しさらに梌筧により磼認した。

\section{3. 実 絬 果}

\section{$3 \cdot 1$ インゴゥト}

インゴット段階での超音波探伤は一般に，形状，表面 状況および取报上，さらには鶖的，冶金学的に不利な条 件が多いのであまり実用的ではないが，Table 1 に示す 方法で行なつた。この結果本実験と類似の寸度で類似の 鋼種のインゴットを探侮する場合，次のような手順に従 えばかなり有益な情報が得られると判断された。

1) 探伤面はグラインダー手入れしなるべく平滑とし た後，記録，データ処理に便利なように，適当なマス目 を記しておく。

2）接触媒貿としてはダリセリンが非常に有奻であ る。探伤は周波数 $1 \mathrm{Mc}, 28 \mathrm{~mm} \oint$ 探触子を用い，峸度 は学振【型 V15-2 が現われる程度に股定する。

3) ブレートの矢陌と直接開係があるのは主にボトム
側の久樎であるので，トップ 側は省略してをよく，なだ トム側は上記感度よりりららに 数 $\mathrm{dB}$ 高くて行なうのがよい。 一方インゴットを $20 \mathrm{~mm}$ 厚にスライスした試料の磁気 探伤では，トッブホホトムと も䫌著なインデイケーション が認められなかつた。超音 波隇衰はブレートより約 10 倍程度大きく，インゴット周 辺と中心部で差が認められ た。

\section{$3 \cdot 2$ スラフ}

スラブ段階での超普波和 はブレートの品質管理上檑め て有効であると考えられ，ま た寸度的にも䔔しているのた 重点をおいて㭘討した。

探賃法としては, $2 \cdot 25 \mathrm{Mc}$ $28 \mathrm{~mm} \oint$ 水晶振動子でシン 油,グリセリンを接蟹媒貿と した直接々触法と， $2 \cdot 25 \mathrm{Mc}$ $22 \mathrm{~mm} \oint$ の局部水漫法を訊㻌 したが，すべての点で水浸法 が有利であつた。感度として は CRT 50\% $=30 \mathrm{~dB}$ (V15$2 \cdot 8=50 \%$ 相当, 詳細交啽 (3)）程度とし、ト,プ任と ボトム側とでは語をかて 記録する必要があつた.ナな わち同一大きさの久宿波でも,ブレ一トになつた場合，ト ッブ側は消失し，ボトム側は残存すること，また而者て は久陌の分布状況打よび平均的大きさが翼なることが羭 明した。 これは欠晔の内容が異なるとしか考えられない ので，スラブ中心部からスライスして探取した試料を践 粉探仵し，さらにインデイケーション部の検镜を行なつ た. 磁粉探侮結果は明らかにトップ側に欠宿が多く， たその寸度も大で超音波の結果と一致した. Photo. 1 r. ミク口組織の一例を示したが，ボトム側は大瑟の介在物 が認められるのに反し，トップ側久陷には介在物状のる のが存在しない，すなわちトッブ側は次行程の压延て死 着する超音波久陥であるが，ボトム側は $\mathrm{Al}_{2} \mathrm{O}_{6}$ 棌の介 在物でこれが牫存して久陮波の源泉となると判断され た.

$3.3>゙ レ-ト$

鋼板に関しての超音波探伤はすでに一般化し，出槏音 などで判定基準むきまつているものもあるが、岁れかれ は欠陥を定责的（数值表示）に取报う方法を碓立してい るので2べ，乙の方法により処理した。

すなわち KRANTKRÄMER の提案した AVG-diagRm 方式を使用した場合，直接法で基染片 Blとの此が 20 $\sim 25 \mathrm{~dB}$ 以上の久陌波が，端面の染色探像でインディケ ーシ・ンを示すことが確かめられてあるので, 先う夙部 水漫法で，直接法と同等威度にして全面探伤し，陌波 
Table 1. Summary of test samples and testing methods.

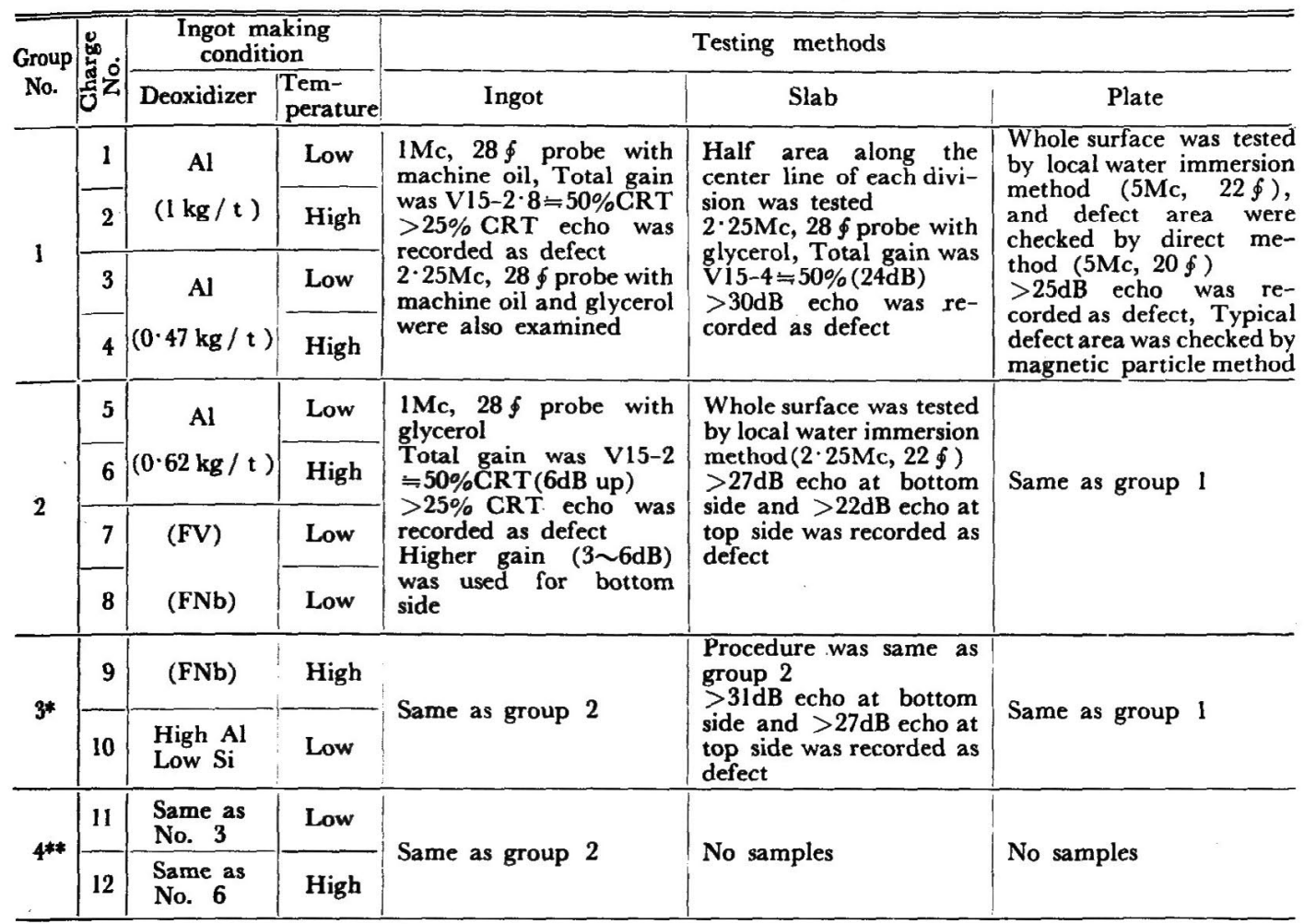

* More samples were taken for checking slab as shown Fig. 1

** Samples for checking ingot

が証められた箇所をさらに $5 \mathrm{Mc}, 20 \oint$ の直接接触法で 精密に再探伤し，その久樎の分布罒を描くこととした。 䊅果の一例を Fig. 2 に示す.この場合久陥が真にポイ ントだけのるのや，若千の拡がりを有するもの，ポイン 卜同志が近いもの，あるいは存在梁さの異なるものなど 㥆々て，裳密な四を描くことは莫大な時間を要し，また

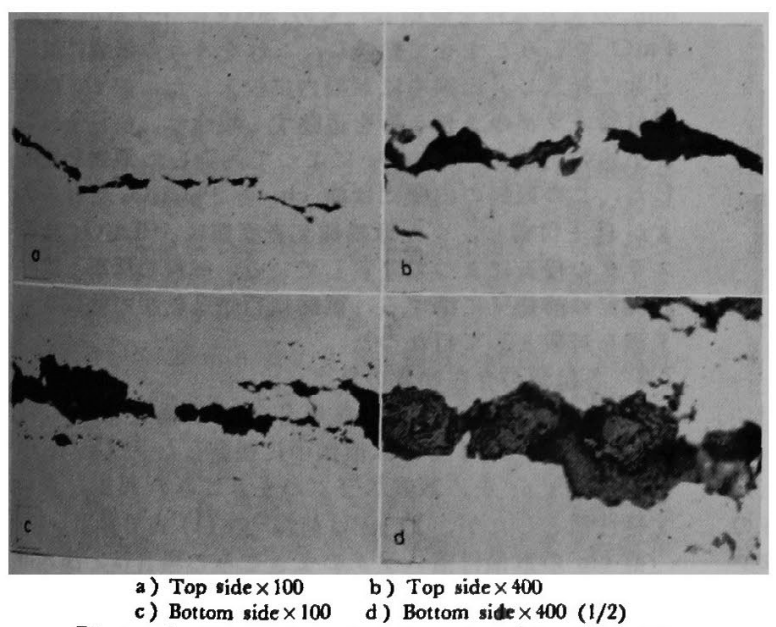

Photo, 1. Examples of defects in slab (No. 10).
その必要性る少ないと考えられるので，欠陥の状況は Photo. 2 に示したように, それぞれの陚料の代表的な 筫所のガス切断面の磁粉探伤図形で示すこととした.

これらの結果から, 最終製品(プレート)としては,

1) 高温出銅と呼ばれるものについては，超音波欠楩 は比較的少なかつた（No. 2, 4, 6, 9).

2) 低温出鋼のものの方がボトム部の欠陷は多 く現われた.

3) 同じ欠宿でも, $\mathrm{Al}$ 脱酸 (No. 1, 3, 5) と Si 脱酸 (No. 7, 8) とでは欠陥の状況が異なる。 すなわち前者での久陥はかなり連続的な大形のイ ンディケーションがほぼ同一層内にあるが, 後者 では板厚方向のかなり広い範囲に分散して存在す る傾向が認められた.

\section{5. 結}

いわゆるラミネーションが発生するような条件 と, そうでない条件で溶製された 60 キ口級高張 力鋼の $6 \mathrm{t}$, インゴット 12 チャージを使用し, インゴットースラブーブレートの一連の流れの中 で, ラミネーションがどのような変化をたどつて いるかを，超音波探傷法で追跡調查した結果をま とめると,

1) インゴット，スラプの全面探傷は，製鋼， 造塊の解析に有効な情報を与えるものと判断され 


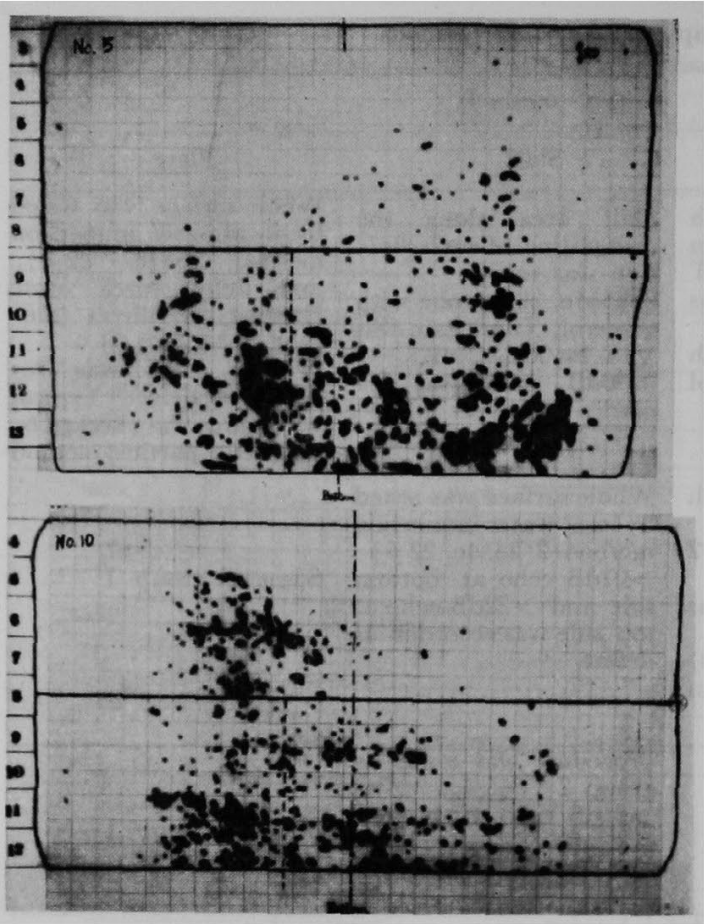

Fig. 2. Distribution patterns of defects in plates detected by ultrasonics.

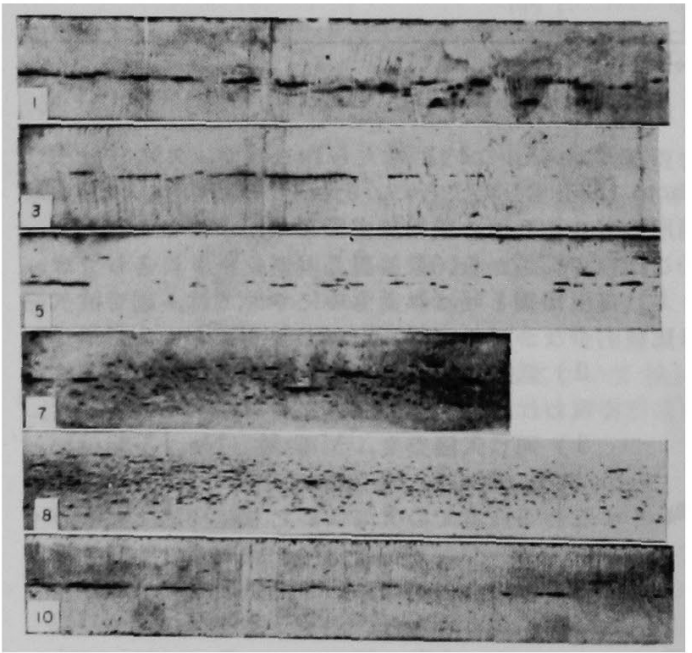

Photo. 2. Typical magnetic particle patterns of deffects in plates detected by ultrasonics. (Indication of defects in plates-30 mm) (The figure shows the charge number)

た.

2) インゴット, スラプの探傷はともに，プレートの 尔陷を予测する上に非常に有力な手段であるが, トッブ 側とポトム側とでは超音波久陥の評価をかえる（適正な 探傷感度を選ら゙）必要がある。
なお塞験の治金学的な結果，考察などについては，別 途報告される予定であるので，ここでは最少限にとどめ た.

\section{女 献}

1) C. Strassburger: Stahl u. Eisen, 81 (196l) 13, p. 885

2）堀田，磯野他：富士弊鉄技報，11（1962）3, p. 153

3 ) 磯野, 中山, 小林: 非破壊検查, 12 (1963) 4, p. 155

4) 村木, 磯野, 吉谷: 鉄と鋼, 49 (1963) 3, p. 583 ；富士製鉄技報， 12 (1963) 4, p. 146

(115)

取鍋スラグのまきこみによる転炉 リムド鋼注入溶鋼中の介在物

（製鋼工場における RI の利用一X V) 八幡製鉄，技術研究所

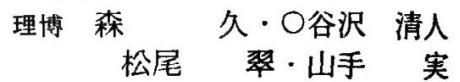

Some Origins of Nonmetallic Inclusion in Pouring LD Rimming Steel

(Tracer application of RI to steel works-XM)

Dr. Hisashi Mort, Kiyohito Tanizawa Midori Matsuo and Minoru Yamate

\section{1. 緒}

言

転妒リムド鋼注入溶鋼中の介在物の起源としては，广 でに転炉内スラグおよび Al 脱酸生成物をとりあげ,介 在物量におよほす製鋼要因の影響をしらべたがい， そ ののち，取鍋スラグのまきこみによる介在物ならびに前 ch. の取鍋付着スラグと取鍋煉瓦变質層のまきこみによ る介在物について，しらベることにした。

\section{2. 実 唤 方 法}

\subsection{RI の取鍋内一の添加}

取鍋スラグのまきこみを追跡する場合は，直徍的 10

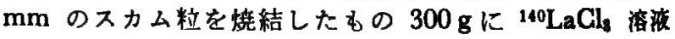

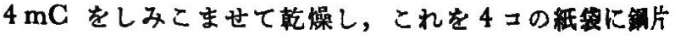
と共に封入し，出鋼中に取鍋内に投入した. 前 ch. の取 鍋付着スラグのまきこみを追跡する場合は, 前報るまよ び上述の試験で ${ }^{140} \mathrm{La}_{2} \mathrm{O}_{3}$ によつて污染した取鍋を使用

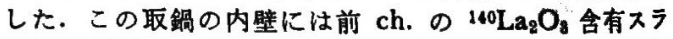
グが若干付着し，また取鍋煉瓦表面層は ${ }^{100} \mathrm{La}_{2} \mathrm{O}_{8}$ 含有 スラグの侵入によつて変貿している. 䬲料の堔取と放射 能測定は前報2にに準ずる. 試験は戸畑 2 転伷で低炭りム

ド銅を対象として行なつた.

\section{2 各起源の介在物量の算出}

取鍋スラグのまきこみの場合は，取鍋に投入した ${ }^{140} \mathrm{La}_{2} \mathrm{O}_{3}$ 量に対する注入㗳銅中に残留した ${ }^{140} \mathrm{La}_{2} \mathrm{O}_{8} の$ 量の比 $Y_{\mathrm{L} . \mathrm{S}^{\prime}}$ を, 取鍋スラグのまきこみの程度を表わ す特性值としたが， $Y_{\mathrm{L} . \mathrm{S}^{\prime}}$ は前報2)の (1) 式て算出した.

前 ch. の取鍋付着スラグのまきこみの場合は，注入漕 銅中に残留する前 ch. の取鍋スラグ含有率 $Y_{\text {R.L.s' }}$ を, 次式で算出した。 
$\boldsymbol{Y}_{\text {R.L.S }}=\left(\boldsymbol{R}_{i} \times M_{s i} / R_{f i} \times M_{i}\right) \times 10^{-6}$ ここで， $R_{i}$ : その蛹塊スカム $740 \mathrm{~g}$ の計数率 $R_{f i}:$ 前 ch. の取鍋スラグ $740 \mathrm{~g}$ の計数率 $M_{s i}$ : その制塊スカムの推定重量 $(\mathrm{g})$ $M_{i}:$ その铜塊の重量 $(\mathrm{t})$

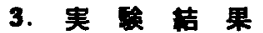

3.1 取鎝スラグのまきこみによる介在物

計 $24 \mathrm{ch}$. の試験を，出鐧時間 $(2 \cdot 1 \sim 6.7 \mathrm{~min})$ および $\mathrm{La}_{2} \mathrm{O}_{2}$ 標識スカム投入時期（出铜時間の $0.19 \sim 0.98$ の 時期）を加えて行なつた。

注入期間におけるみかけの浮上分謨速度俰数は, 0.035 $\pm 0.021(\sigma) \mathrm{min}^{-1}$ であつた。この場合の残留する ${ }^{40} \mathrm{La}_{2} \mathrm{O}_{3}$ の割合の自然対数と出銅終からの時間との回㷌 式加，各 ch. について出銅終から $20 \mathrm{~min}$ 後の溶鍶中 に牫留する ${ }^{1 * 0 \mathrm{La}_{2} \mathrm{O}_{3}}$ の割合 $(\%)$ の自然対数 $Y_{\mathrm{LS}}$ を算 出し,との値に影整すると思われる要因として, ${ }^{140 \mathrm{La}_{2} \mathrm{O}_{8}}$ 投入加ら出鍃終までの時間 $x_{1}(\mathrm{~min}),{ }^{140} \mathrm{La}_{2} \mathrm{O}_{3}$ 投入時 期 $x_{2}\left(x_{1} /\right.$ 出金時間 $\left.(\mathrm{min})\right)$ および出銅中期の取铜内溶 筫逐度 $x_{3}\left({ }^{\circ} \mathrm{C}\right)$ の 3 要因をとりあげて重回㷌分析した 結果, 以下の回挶式が得られた。

$$
Y_{\mathrm{L} . \mathrm{S} .}=-0.431 x_{1}+2 \cdot 835 x_{2}^{*}+0.0225 x_{\mathrm{g}}-39 \cdot 61
$$

(*は㴜相関係数が $5 \%$ 有意)….........(2)

出筑籍より $20 \mathrm{~min}$ 後の ${ }^{140} \mathrm{La}_{2} \mathrm{O}_{3}$ の残留割合の実閏值 を(2) 式の $x_{3}=1580^{\circ} \mathrm{C}$ として補正した值と， ${ }^{140} \mathrm{La}_{2} \mathrm{O}_{3}$ 投入時期との関保を Fig. 1 に示す.この图:は， $x_{3}$ か $1580^{\circ} \mathrm{C}$ として，出鋼時間が 2,4 もしくは $6 \mathrm{~min}$ （2）式に代入した結果をあわせて示す。この罒をみる と，出策初期に $\mathrm{La}_{2} \mathrm{O}_{8}$ を投入するほど ${ }^{140} \mathrm{La}_{2} \mathrm{O}_{3}$ の残留

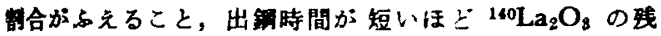

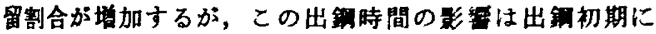
${ }^{100} \mathrm{La}_{2} \mathrm{O}_{3}$ を投入するほど著しいことがわかる。しかし， Fig.1と（2）式からしかかるように，(2) 式の信頼生 は，前報および後述の他の 3 種の試験に比べて，かなり 低い。

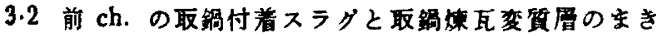
こみによる介在物

計 29ckt.の試駼を行なつた。出銅時間は $2 \cdot 3 \sim 7 \cdot 4$ $\min て ゙$, 前 ch. の取鍋付着スラグおよひ変質居に侵入 したスラグ量 $x_{2}^{\prime}$ は 50〜440 kg であつた， $x_{2}^{\prime}$ は， $x_{2}^{\prime}=$

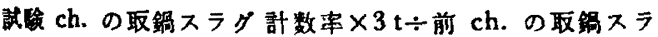
グ訴数事，なる式で算出した。

注入期間中のみかけの浮上分䧿速度倸数注，0.036士 0.042 $\mathrm{min}^{-1}$ であつた。ただ，実的法からも明らかな ように，との試験では RIの使用量が少なく，したがつ てスカムの計数事が低かつたため，注入順の各銅塊スカ ムの計数事のバラッキが著しかつた。

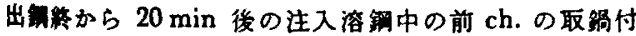
萧スラグ量 $Y_{\mathrm{R}} \mathbf{L}$.s. を後述の（3）式で $x_{2}^{\prime} か ゙ 170 \mathrm{~kg}$ で あると補正して，とれと出銅時間 $x_{1}$ との関俰を，出銅

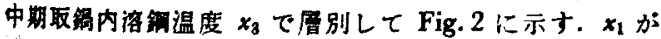

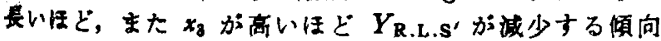
がうかがえる. そこで，前 ch. の取铜付音スラグ起源介

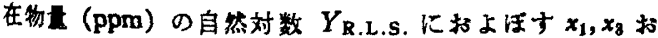
よひ $x_{2}$ (前 ch. の付着スラグ量 $x_{2}^{\prime}(\mathrm{kg}){ }^{\star}$ の自然対数) の3要因の重回师分析を行ない，次式を得た。

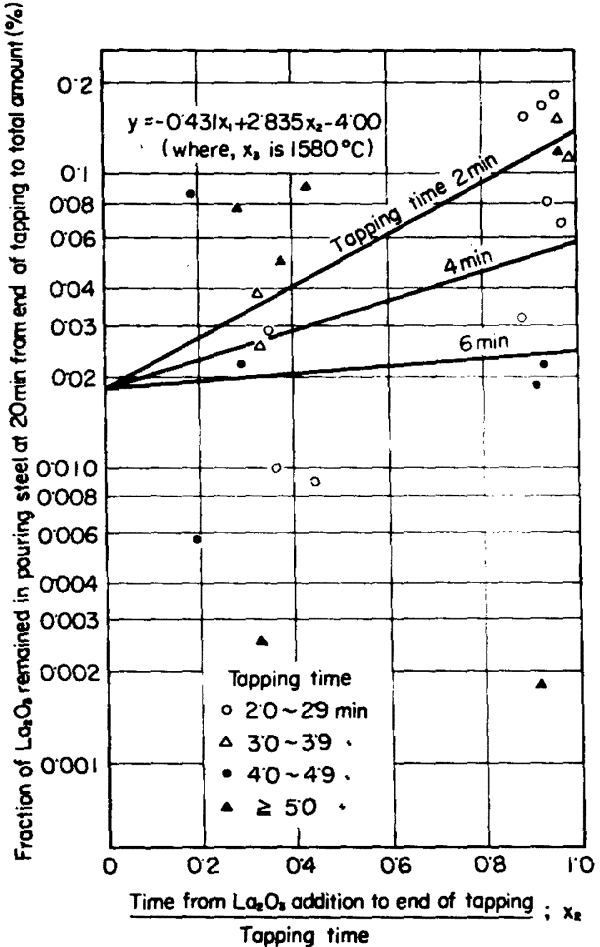

Fig. 1. Relation between time of $\mathrm{La}_{2} \mathrm{O}_{3}{ }^{*}$ addition and fraction of $\mathrm{La}_{2} \mathrm{O}_{3}$ remained in pouring steel.

(* $\mathrm{La}_{2} \mathrm{O}_{3}$ was tagged to sintered slag)

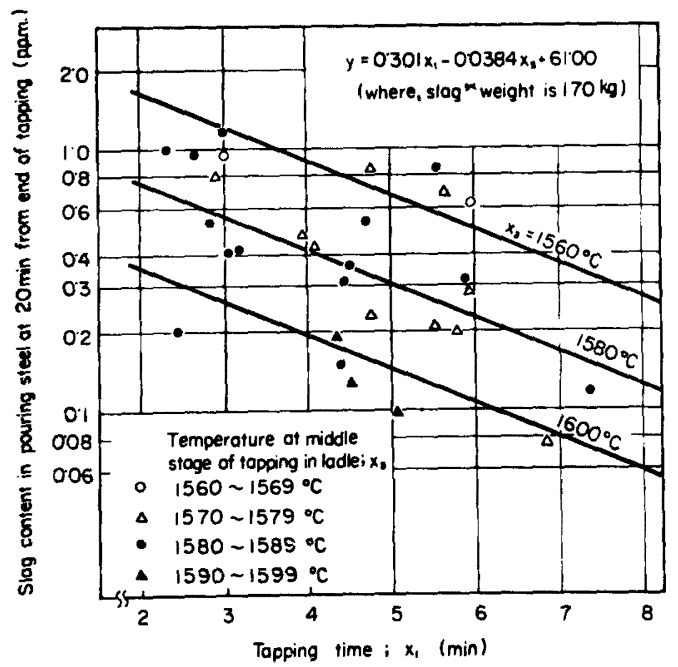

Fig. 2. Relation between tapping time and slag* content in pouring steel.

(* The slag originated in ladle slag of last charge) 
Table 1. Content of nonmetallic inclusions in pouring steel.

\begin{tabular}{l|l|c}
\hline \hline Origin & $\begin{array}{c}\text { Contentin pouring } \\
\text { steel (\%) }\end{array}$ & $\begin{array}{c}\text { Assump- } \\
\text { tion }\end{array}$ \\
\hline \begin{tabular}{l|l} 
Furnace slag \\
Ladle slag
\end{tabular} & $\begin{array}{l}0.0015 \sim 0.0001 \\
0.001 \sim 0.0001\end{array}$ & (1) \\
Ladle slag of last charge & $\begin{array}{l}\text { Lesst han } 0.0001 \\
0.003 \sim 0.00002\end{array}$ & (2) \\
\hline
\end{tabular}

(1) Al addition to ladle is $70 \mathrm{~g} / \mathrm{t}$

(2) Ladle slag discharged at beginning of tapping to $150 \mathrm{t}$ ladle is $750 \mathrm{~kg}$

$$
\begin{aligned}
& Y_{\text {R.L.S }}=-0 \cdot 301 x_{1}^{* *} \\
& +0.327 x_{2}-0.0384 x_{3}^{*}+59.321 \\
& \text { （*は } 5 \% \text { 有意，**は } 1 \% \text { 有意） } \\
& \text { 4. 考 察 }
\end{aligned}
$$

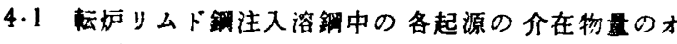
一ダー

前報および本報の結果に仮定を入れて，各起源の介在 物量を推定した結果を，Table 1 に示す．ここに示した 健は，まきこまれたスラグの組成が変化することなく溶 銅中に残留すると仮定して算出した值であつて，むしま きこまれたスラグが他の成分と結合して希絼されている とすれば，その希䣋された倍事をこの值に乗ずる要があ る.また，炉内スラグが出鋼時に取鍋に排出してまきこ まれるはずであり，䇴密には，妒内スラグ·取鍋スラグ 前 ch. の取鍋スラグが一部重復して計上されていると考 えるべきであり，これら 3 種の起源の介在物量を合計す ると，スラグ系起源介在物の全量を過大に見䅡る可能性 があることに留意されたい。

4.2 取鍋保持時間中の $\mathrm{Al}$ 脱酸生成物とスラグ莱介在 物の浑上状況の差異について

困は省略するが，同一ch.の各銅塊スカ厶の放射能 を注入䫆にブロットしてみると，炬内スラグおよび取鍋 内スラグ起源介在物については，中高の傾向一すなか ちNo. 1 铜塊に比べて No. 3 もしくはNo. 5 铜塊スカ ムの放射能が高くなり，以後は注入順に減少して最終䨐 塊に至つて著しく娍少する㑯向——を示す例が多いが， La 脱酸生成物では中高の傾向を示す例が少なかつた。 前 ch.の付着スラグについては，前述した理由のために 計数誤差が大きく，一定の傾向は認められなかつた。 た，前述したように，注入期間中のみかけの浮上分離速 度俰数は, La 脱酸生成物では $0.020 \mathrm{~min}^{-1}$ であるの に，スラグ系介在物は 0.031〜0.036であり，スラグ系 の方が 2 倍近く大きかつた。これらの現象は以下のよう に解积できょう。

取鍋内銅浴溔的対流なとによつてかなり混合される とはいえる), 取锅保持時間が長くなると次第に鋼浴の高 さ方向に温度差が生(゙)，底部付近の銅浴は静止浴に近 くなると推测される．取鍋内の温度分布ならびに対流状 洗がこのようになつた時点で注入を開始すると，ノズル から出る塎鑐は，まずノズル近くのもの，ついで上部浴 の䐓となり，最後に取鍋下部のノズルから遥い部分が流 出することが，水によるモデルで浴内の温度分布ならび に注入流の温度変化の测定結果引)や水にインクやスチレ
ン樹脂を加えて注入中の浴内の流れを観察した実験わ゙で 明らかにされている、いま，スラグ系介在物は平均粒度 が大きくかつ粒度分布の巾む広いと仮定すると，スト一 クス則による浮上》の結果，取鍋保持時間中に銅浴高さ 方向に介在物の著しい浱度勾配を生じ，この時期に注入 を開始すると，まずノズル近傍の介在物沄度の低い洛鈵 が流出し，ついで介在物濃度の高い取銅上部の溶銿が流 出し，最終鋼塊付近でふたたび介在物浱度の低い取鍋下 部のノズルから遠い部分が流出し，かつ注入期間中にる 鋼浴内の介在物分離がかなり進行する結果, 銅塊スカム 放射能の注入順の推移が右下りの中高の曲線となつたる のであろう。一方， $\mathrm{La}_{2} \mathrm{O}_{3}$ は粒度が小さく，ストークス 則による浮上速度がスラグ系介在物のそれに比べてかな り小さいと仮定すると，注入直前の鋼浴高さ方向の介在 物の浱度勾配はスラグ系介在物に比べて小さく，したが つて铜塊スカム放射能の注入順の推移は中高の傾向が少 なく，注入期間中の介在物の浮上がほとんど進行しない ために右下りの勾配（みかけの浮上分離速度俰数）む小 さいことになる。

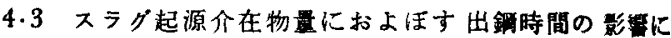 ついて}

取鍋内スラグが出鋼流によつてまきこまれる速度 $\boldsymbol{V}$ は, 出銅初期ほど出銅流の落差が大きく取鍋内鍴浴が浅 いために大きく，出鋼時間 $T$ が短いほど出鋼速度が大き いために大きく，出鎆閶始からの時間とともにVが诚少 すると想像される。

そこで, $V=A-k_{1} t$ なる関数形で, $A \infty 1 / T, k_{1} \infty 1 / T$ である仮定し，一旦溶龬にまきこまれたスラグの浮上分 離は $k_{2}=0.8 \mathrm{~min}^{-1}$ なる速度係数で 1 次則にしたがつて 進行すると仮定すると，取銆内鋼浴にまきとまれている スラグ量Cの解として次式を得る。

$$
C=\frac{1}{k_{2}}\left[A-k_{1}\left(t-\frac{1}{k_{2}}\right)\right]-\frac{1}{k_{2}}\left(A+\frac{k_{1}}{k_{2}}\right) \exp \left(-k_{2} t\right)
$$

（4）式から，銅浴中にまきこまれているスラグ量Cと 出鋮始からの時間 $t$ との関係を算出してプロットしてみ ると（四は省略），上に凸の曲線で增加して $\max$ に连し て後ふたたび下降するが，出銅時間が長い注ど $\max に$ 達する時期 $(t / T)$ が早く, $\max$ の值も低く，また出嗤 終の值も低くなる.

前報1 における注入溶鏢中の妒内スラグ貫および 3.2 で示した $Y_{\text {R.L.S }}$ は，出鋼終から注入までの浮上分隻勾 配が ch.によらず一定であると仮定すると，(4) 式で算 出される出鋼時の $C$ と比例するはずであり，実駼結果と （4）式による推測とはみかけ上一致している. また， 3.1 の結果では, 出時間が長くなると $\mathrm{La}_{2} \mathrm{O}_{8}$ 投入時 期の影留が 小さくなつたが，これむ $\mathrm{La}_{2} \mathrm{O}_{3}$ 投入時期以 後にまきこみが閒始したと仮定して满出した（4）式と 類似の式による推測とみかけ上一致している.

しかし，このようなモデルが妥当であるか否かは，今 後エマルジッン化能の異なる各種の界面活性削と油を使 用して，水一油系のモデル実験などを行なうことによつ て確かるる要があろう。

\section{5. 赫}

以上，枟ねリムド鋼注入溶銅中の介在物の起源とし 
て, La 跘酸生成物や各種のスラグ系介在物について定 量的に検討したところ，常識から年想された溶鋼温度や

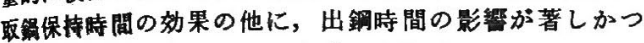
たととは，注目すべきことと考えられる。

$$
\text { 文献 }
$$

1）森，他：鉄と鋼，51（1965)，p. 1930

2) 森, 他: 同 上, 52 (1966), p. 1552

3) 森, 他: 同 上, 50 (1964), p. 442

4) 例えば N. L. Samways and T. E. Dancy: J. of Metals, 12 (1960), p. 331

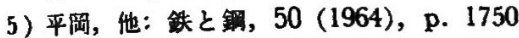

6) 大久保，他：同上, 52 (1966)，p. 440

7) 例えば, 宮下, 他: 同上, 52 (1966), p. 1454

\section{（116）大型リムド鋼塊内の非金属介在物} の分布について

（リムド鋼塊の非金属介在物に関する研究－I） 富士製鉄，広畑製鉄所

浅野鋼一・大橋徹郎・O塗 嘉夫

On Distribution of Nonmetallic Inclusions in Large Rimming Steel Ingot

(Study on nonmetallic inclusions in rimming steel ingot-I)

Köichi Asano, Tetsurō ŌHashi and Yoshio NURI

\section{1. 緒言}

低炭素りムド銿は命延鋼板をはじめとして，熱延中薄 板にまて広く用いられている。このリムド銅板の特質が 清净なリム層を有するために，その加工性が良好で，か つ成品表面が美簏である。

しかし，最近加工技術の進歩とともに高度の加工が要 求され従来あまり問題とされなかつた諸欠陌がクローズ アップされてきており，それらの久陷の多くが非金属介 在物に起因するすのであるといわれている，従来，リム ド铜塊の非金属介在物に関しては 2，3 の研究がある が1) 、8，いまだ不明な点が多い，特に，リムド鋼の非金 属介在物の研究を困難にしている理由の1つに適切なる 定量方法が確立されていないことがある。

著者ら㹥として，スライム法により大型介在物を抽

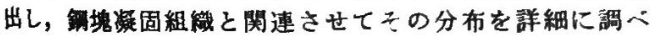
たのでその結果を報告する.

\section{2. 実 験 方 法}

枟炉溶製極軟リムド銅を大型鋳型に注入し，試験銅塊 を作成した．試験鋼塊の製銅造塊条件および鋳型の主要 寸法を Table 1 に示す. 試験鋼塊は泠塊後, 鋼塊の縱 方向の中心線を通つて 1/4 を削り落し，その切削面に ついて各種位置から試料を採取した，試料探取位置は Photo. 1 のマクロエッチ写真上に示した。 リム層で頭 部，中央部，底部と 3 個採取し，リム層とコフ部の境界 で司しく4コ採取しコフ部，センター部では濃厚偏析带 它含めて 9 , 合計 16 個の試料を採取し, スライム用 の試料とした．また同時に酸素分析用試料を䠃塊䫓部，
Table 1. Teeming conditions and mold dimensions of tested ingot.

\begin{tabular}{|c|c|c|c|}
\hline \multicolumn{2}{|c|}{ Tap temperature $\left({ }^{\circ} \mathrm{C}\right)$} & & 1580 \\
\hline \multicolumn{2}{|c|}{ Ladle analysis $(\%)$} & $\begin{array}{l}\mathrm{C} \\
\mathrm{Mn} \\
\mathrm{S}\end{array}$ & $\begin{array}{l}0 \cdot 07 \\
0 \cdot 30 \\
0 \cdot 017\end{array}$ \\
\hline \multicolumn{2}{|c|}{ Mold addition of $\mathrm{Al}(\mathrm{g} / \mathrm{t})$} & \multicolumn{2}{|r|}{67} \\
\hline \multicolumn{2}{|c|}{ Capping time ( $\min$ ) } & \multicolumn{2}{|r|}{27} \\
\hline Mold dimensions & $\begin{array}{l}\text { Width ( mm) } \\
\text { Thickness ( mm) } \\
\text { Height ( mm) }\end{array}$ & & $\begin{array}{l}860 \\
850 \\
200\end{array}$ \\
\hline \multicolumn{2}{|l|}{ Ingot weight $(t)$} & & $22 \cdot 0$ \\
\hline
\end{tabular}

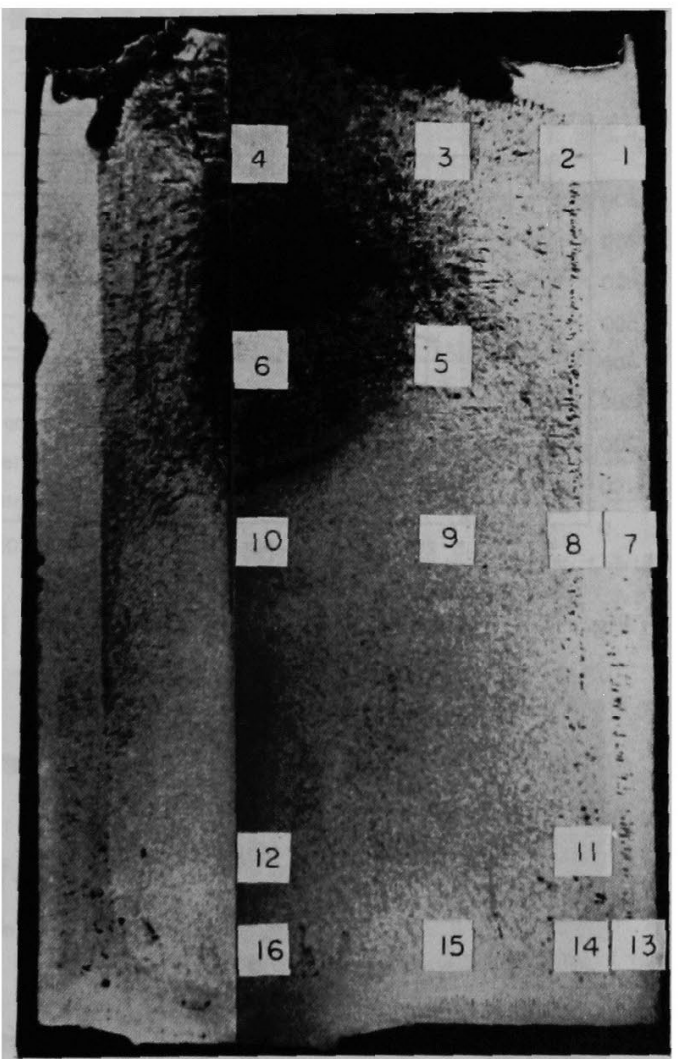

Photo. 1. Position of samples for slime-method.

中央部，底部にて巾方向に連続的に探取した。

スライム法については，すでに 2，3 報告されている が以下にその操作要領を示す1)(3).

䥜塊より切り出した試片（約 $5 \mathrm{~kg}$ ）を陽極とし 10 $15 \%$ 塩化第 1 鉄水溶液を電解液とし数連直列で 10 20 $\mathrm{V}, 10 \sim 15 \mathrm{~A}$ の条件で 30 日〜40 日間通電して電解を おこなつた：除極には $3 \mathrm{~mm}$ 目， $0.7 \mathrm{~mm} \oint$ の金網を 使用し, 電解中陰極からの電解鉄片の脱落を防止するた 